\title{
Pharmacognostical Studies and Determination of Total Flavonoids of Paitan (Tithonia diversifolia (Hemsl.) A. Gray
}

\author{
Vera Ladeska*, Ema Dewanti, Deviana Indah Sari
}

\section{Vera Ladeska*, Ema Dewanti, Deviana Indah Sari}

Faculty of Pharmacy and Sciences, University of Muhammadiyah Prof. Dr.Hamka, Jakarta, INDONESIA.

\section{Correspondence}

Vera Ladeska

Faculty of Pharmacy and Sciences, University of Muhammadiyah Prof.

Dr.Hamka, Jakarta, INDONESIA.

E-mail: v_ladeska@yahoo.com

History

- Submission Date: 19-12-2018;

- Review completed: 12-06-2019;

- Accepted Date: 28-07-2019.

DOI : 10.5530/pj.2019.11.195

Article Available online http://www.phcogj.com/v11/i6

Copyright

(C) 2019 Phcogj.Com. This is an openaccess article distributed under the terms of the Creative Commons Attribution 4.0 International license.

\begin{abstract}
Tithonia diversifolia (Hemsl.) A. Gray is one of the plants used in traditional medicine and belongs to Compositae family. In different parts of Indonesia, it is commonly known as "paitan and kembang bulan". The study provides an early description of Tithonia diversifolia (Hemsl.) A. Gray) and complete the monographs data extract. This plant prospects to the main source of the raw material for the herb-drug product and some parameters identified were needed to ensure the safety, quality and efficacy of the product. The present study is to evaluate macrosand microscopic characteristic of the Indonesian plant and its quality parameter including fluorescence, physicochemical characteristics and phytochemical screening. Moisture content, ethanol and water-soluble extract was determined, and were discovered to be $11,27 \%, 4,73 \%$ and $18,01 \%$. Total ash value and acid insoluble ash value were determined which was 10.29 and $0.72 \%$ respectively. Phytochemical screening of aqueous ethanol extract of Tithonia diversifolia showed the presence of alkaloids, flavonoids, tannins, saponins and triterpenoids. The result showed that average content of flavonoid total is $69.1653 \mathrm{mg}$ QE/g extract.

Key words: Pharmacognostical, Physicochemical, Phytochemical, Tithonia diversifolia (Hemsl.) A. Gray).
\end{abstract}

\section{INTRODUCTION}

Tithonia diversifolia is potential prospect as traditional medicine, a study for quality and quantity control is needed to provide a scientific base about pharmacognostic specification. Tithonia diversifolia is a plant species belonging to the Compositae family. In different parts of Indonesia, people commonly known as "paitan and kembang bulan" and also used in Indonesia traditional medicine This plant is native to Mexico and Central America. Tithonia diversifolia can grow naturally in Indonesia and other Southeast Asia countries. Tithonia diversifolia leaves have antioxidant compounds because of its flavonoids. ${ }^{1}$ The flavonoid compounds present in this "paitan "leaf are pentahidroksiflavonol. ${ }^{2}$ In addition to flavonoids, these plants also contain alkaloids, tannins, saponins and triterpenoids. ${ }^{3}$

Based on several studies it has been shown that paitan leaves have cytotoxic effects on colon cancer cells, ${ }^{4}$ antihyperglycemic ${ }^{5}$ and antidiarrheal activity that may inhibit intestinal motility ${ }^{3}$ because of its flavonoid content. Flavonoids are one of the most common groups of secondary metabolite compounds found in plant tissues and have many important functions for health, such as antioxidants, ${ }^{6}$ antibacterial, anti-inflammatory, allergic and antithrombotic. ${ }^{7}$

Considering the potency of Tithonia diversifolia as medicinal plants, it is necessary to make the pharmacognostical studies and phytochemical screening. In this study, the specific and nonspecific parameters were tested to determine the quality of the extract using methods described in the Farmakope Herbal Indonesia (FHI is the Indonesian Herb Pharmacopoeia, 2008) and to determine the level of flavonoids in paitan leaf extract. This preliminary study helped for standardization of the crude drug as well as further processing of the sample with some indication regarding the nature of chemical coumpounds present in it.

\section{MATERIALS AND METHODS}

\section{Collection and authentication}

The plant of Tithonia diversifolia (Hemsl.) A. Gray) were collected from Botanical Garden, Bogor, West -Java, Indonesia. The botanically identified at Herbarium Bogoriense, Bogor Indonesia.

\section{Pharmacognostical evaluation}

\section{Macroscopic study}

Determining the characteristics of paitan (Tithonia diversifolia (Hemsl.) A. Gray) plants by direct observation of the physical form of fresh plants includes roots, stems, leaves, flowers, fruits and seeds.

\section{Microscopic study}

Microscopic study of the transverse sections of fresh leaves paitan and material powder. Using chloralhydrate and fluoroglusin reagens and then it was heated on spirit lamp. Specific fragment were observed under the microscope and were photographed. $^{8}$

\section{Extraction method}

Extraction is done by maceration of one part of paitan leaf with $70 \%$ of ethanol within 10 parts. Soak for the first 6 hours while mixing it up 3 times every 
2 hours, afterwards let it rest throughout 18 hours. The extraction was filtered out and concentrated using a vacuum rotary evaporator and the extracts that were obtained are concentrate.

\section{Physicochemical parameter study}

a) Moisture content

Determination of water content is done by distillation toluene. ${ }^{9}$

\section{b) Total ash value}

Weigh accurately 2 gms of the extract and put it into crushed silicate crucible which was previously ignited and weighted. Spread the extract material in a fine even layer at the bottom of the crucible and ignite it by gradually increasing the heat to $400^{\circ} \mathrm{C}$ until it changes color to white. The crucible was cooled in a desiccator and weighed. Procedure was repeated until constant weights were obtained. ${ }^{9}$

\section{c) Acid insoluble ash content}

The total ash obtained above was boiled with $25 \mathrm{ml}$ dilute hydrochloric acid for 5 minutes.

The insoluble ash was collected on ash free filter and washed with hot water, then transferred into pre weighed silica crucible, ignited, cold and weighed. The same procedure was repeated until the constant weight was obtained. ${ }^{9}$

\section{d) Water soluble extract value}

Firstly, 5 gms of extract were put into a glass-stopper conical flask, then adding $100 \mathrm{ml}$ chloroform saturated water, shake it up for the initial 6 hours, and then leave it throughout 18 hours. Afterwards $20 \mathrm{ml}$ filtrate were dried at $105^{\circ} \mathrm{C}$ and weighed. The percentage value of water soluble extract was calculated with reference to the air dried drug. ${ }^{9}$

\section{e) Ethanol soluble extract value}

Firstly, 5 gms of extract were put into a glass-stopper conical flask. Macerated with $100 \mathrm{ml}$ of $95 \%$ ethanol, shake it up for the initial 6 hours, and then leave it throughout 18 hours. Afterwards, $20 \mathrm{ml}$ filtrate were dried at $105{ }^{\circ} \mathrm{C}$ and weighed. The percentage value of soluble extract was calculated with reference to the air-dried drug. ${ }^{9}$

\section{FLUORESCENCE CHARACTERISTICS}

Fluorescence characteristic of powdered and extract material was observe with different chemical reagents. The samples were inserted on the plate and dripped different chemical reagents. The reagents were $2 \mathrm{~N}$ hydrochloric acid, 50\% sulfuric acid, $50 \%$ nitrite and $5 \%$ sodium hydroxide and then observed under visible and ultraviolet (254 and 366 $\mathrm{nm})$ light. ${ }^{10}$

\section{PHYTOCHEMICAL SCREENING}

Preliminary phytochemical screening was carried out using $20 \mathrm{~g}$ powdered material and subjecting it to successive extraction in a reflux apparatus with $200 \mathrm{ml}$ ethanol $70 \%$ for 30 minutes. The extraction was filtered and concentrated using a rotary evaporator. This extract were being tested for its alkaloids content using Dragendorff, Mayer and Bouchardat reagents, flavonoid test (Shinoda and ammonia test), tannin test (test with gelatin and $\mathrm{FeCl} 3$ ), saponin test (foam test) and steroid and terpenoid test (Liebermann Burchard test).

\section{CHROMATOGRAPHIC PROFILE}

Chromatographic profile were performed on hexane extract, dichloromethane extract (DCM), 70\% ethanol extract by maceration. The extraction was continued until the solvent became colourless. Those 3 extracts were concentrated utilizing rotary evaporator thereupon analyzed by TLC. Silica gel 60 GF 254 TLC plates were used for the profile of the chromatographic. Each extract was lightly dissolved in ethanol and capillary tube were used to uniformly apply the dissolved samples on the plates and allowed to dry. The plates were developed in a chromatographic tank using the different solvent system as HexaneDCM (4:6), Kloroform-Metanol (9:1) and Etil asetat-etanol (5:5). The plates were dried and observed under visible light and ultraviolet light $366 \mathrm{~nm}$ and by spraying with $10 \%$ sulfuric acid followed by heating at $105^{\circ} \mathrm{C}$ for 5 minutes in an oven. ${ }^{11}$ The retention factor (Rf) value was calculated using following formula.

$\mathrm{Rf}=$ Distance moved by the solute/compound

Distance moved by the solvent front

\section{DETERMINATION OF TOTAL FLAVONOID CONTENT}

\section{Qualitative analysis}

The standard solution of quercetin and ethanol extract of paitan leaves was slightly dissolved in ethanol and capillary tubes were used to apply the dissolved sample on the plates in uniformity and allowed to dry. The plates were developed in a chromatograhic tank using solvent system as ethyl acetate - acetic acid- water (7:2:1).

\section{Quantitative analysis}

\section{Preparation of standard solutions}

Determination of total flavonoid levels contained in the extract was done using quercetin as standard to make the calibration curve. Quercetin was weighed to $10 \mathrm{mg}$ dissolved in $96 \%$ ethanol in order to achieve $10 \mathrm{ml}(1000 \mu \mathrm{g} \mathrm{ml})$ solution, then diluting $40,35,30,25$, and $20 \mu \mathrm{g} / \mathrm{ml}$. Out of these concentrations were taken sequentially $0.4 ; 0.35$; $0.3 ; 0.25$; and $0.2 \mathrm{ml}$ of solution, added $3 \mathrm{ml}$ of $96 \%$ ethanol, $0.2 \mathrm{ml}$ $\mathrm{AlCl} 310 \%, 0.2 \mathrm{ml}$ of $1 \mathrm{M}$ natrium acetate, then add the aquades until it's up to $10 \mathrm{ml}$. The incubate the solution mixture for 30 minutes at room temperature, measured its absorbance at a $440 \mathrm{~nm}$ wavelength using a UV-Vis spectrophotometer.

\section{Preparation of sample solution}

Preparation of sample using 1 gram of paitan leaf extract, add $96 \%$ ethanol until it's up to $10 \mathrm{ml}$ volume $(100.000 \mu \mathrm{g} / \mathrm{ml})$. Then taken 1 $\mathrm{ml}$ and diluted $5,000 \mu \mathrm{g} / \mathrm{ml}$, then taken $1.0 \mathrm{ml}$ to add $3.0 \mathrm{ml}$ of $96 \%$ ethanol, $0.2 \mathrm{ml} \mathrm{AlCl} 310 \%, 0.2 \mathrm{ml}$ of $1 \mathrm{M}$ natrium acetate and add the aquades it's $10 \mathrm{ml}$ of value. The solution mixture was incubated for 30 minutes at room temperature, then measured its absorbance at $440 \mathrm{~nm}$ wavelength using UV-Vis Spectrophotometer. The result obtained is calculated by linear regression equation between quercetin concentration relationship with absorbance. ${ }^{12-14}$

$\mathrm{y}=\mathrm{bx} \pm \mathrm{a}$

Notes:

$y=$ Absorbance of sample

$\mathrm{x}=$ Total flavonoid concentration $(\mu \mathrm{g} / \mathrm{ml})$

$\mathrm{a}, \mathrm{b}=$ Constanta

\section{RESULTS AND DISCUSSION}

\section{Macroscopic images of Tithonia diversifolia}

Macroscopic characters is done by observing the physical form of paitan plants that aims to determine the characteristics of paitan plants. The results showed that the plant has a characteristic a single leaf shape, alternatus leaf and inflorecentia cymosa has two types of flowers are sterile flowers and fertilized tube flowers. ${ }^{15-18}$ Microscopic observation 
results show on longitudinal sectional paitan powder have specific fragments of glandula hair and anomocytic type stomata (Figures 1-7).

Phytochemical screening was performed to observe the secondary metabolite in Tithonia diversifolia leaf extract. Results showed the extract contains alkaloids, flavonoids, saponins, tannins and triterpenoids.

Physicochemical parameters of ethanol extract of $70 \%$ paitan leaf include total ash value, acid insoluble ash value, water soluble extract value, ethanol soluble extract value and moisture content can be seen in Tables 1 and 2. Determination of total ash value was done in order to give description of content internal and external minerals derived from the initial process until the formation of the extract. Determination of water-soluble concentration and ethanol was conducted to give an early study of the number of compounds that can be dissolved with water solvents and ethanol from a simplicia. ${ }^{9}$

Chromatographic profile of $\mathrm{n}$-hexane extract, dichloromethane (DCM), and $70 \%$ ethanol extract was done. Determination of chromatographic profile aims to know the characteristics of chromatography based on the level of polarity. ${ }^{19}$ The result above shows that chromatographic profile of n-hexane extract obtained 6

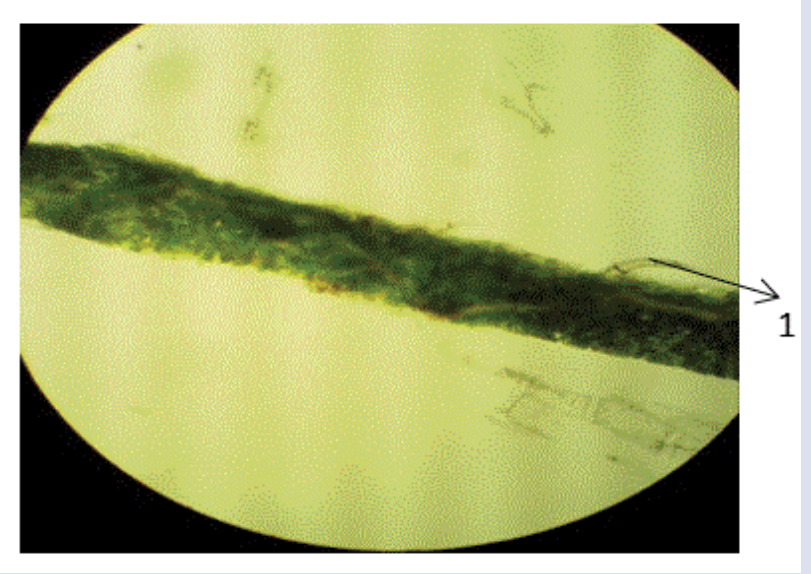

Figure 1: multicellular trichomes on longitudinal sectional paitan leaf.

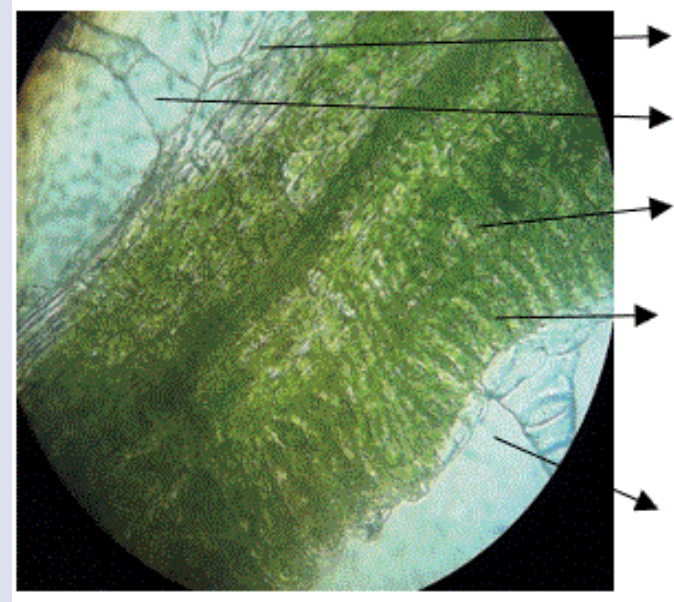

Figure 2:

(1) upper epidermis

(2) multicellular trichomes

(3) coral flower tissue

(4) palisade

(5) lower epidermis

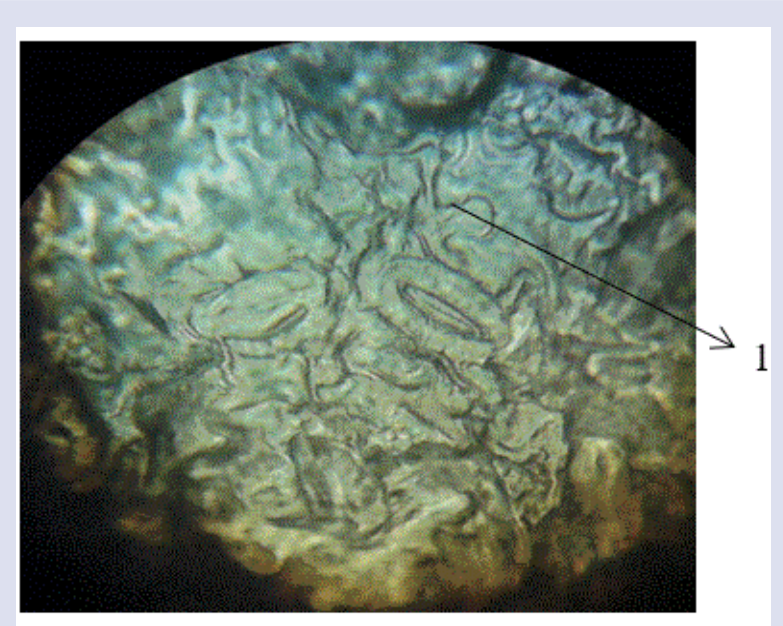

Figure 3: Anomocytic type stomata on transversal sectional (1).

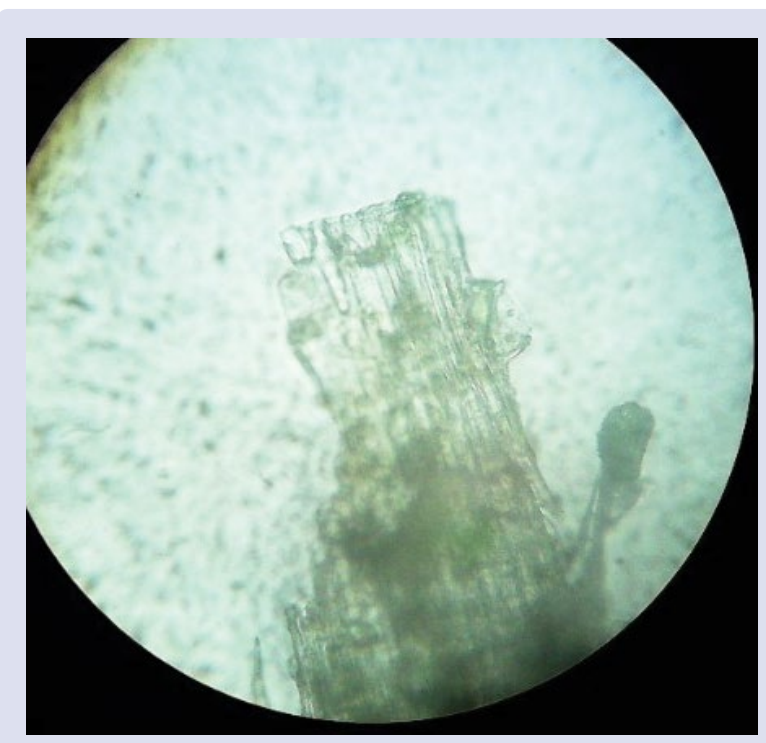

Figure 4: Mesophyl fragmen on transversal sectional.

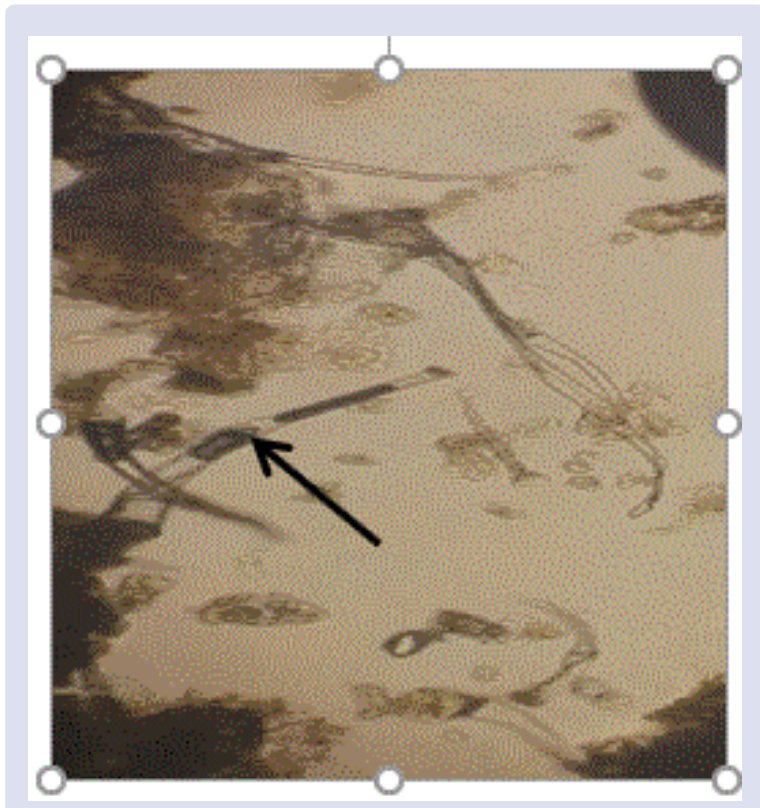

Figure 5: Multicellular trichomes. 


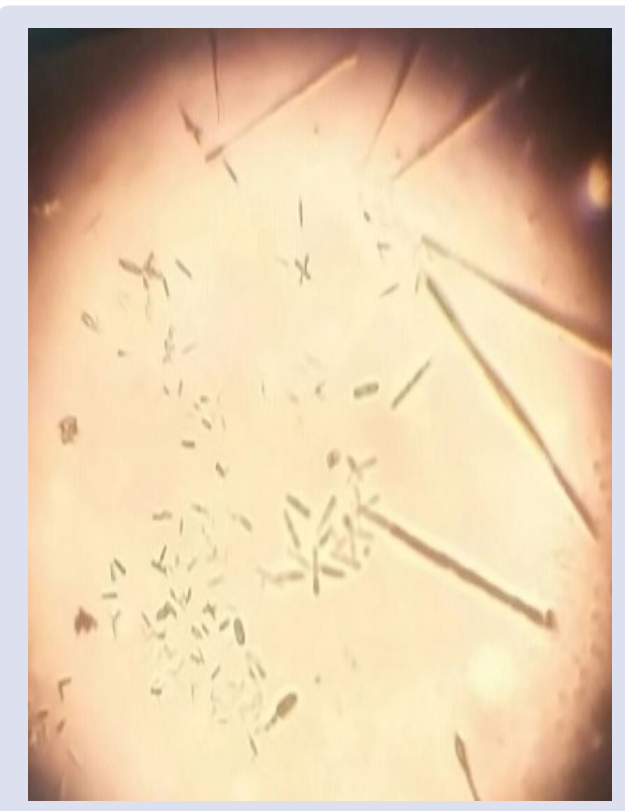

Figure 6: Calcium oxalate crystals.

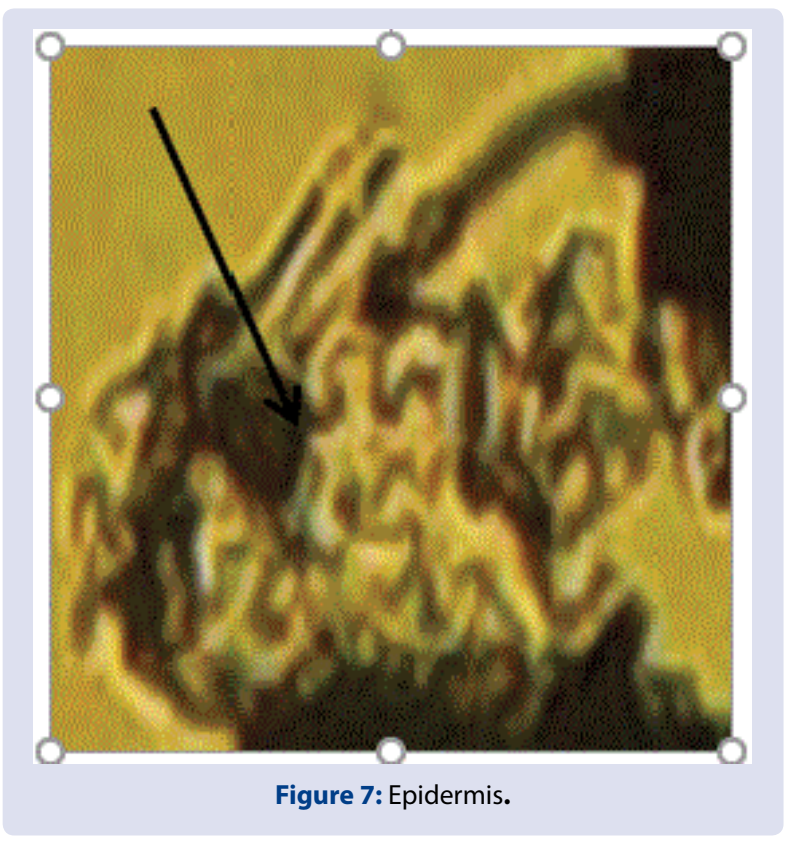

Table 1: Phytochemical screening of material plant extracts of Tithonia diversifolia.

\begin{tabular}{ccc}
\hline Phytoconstituens & Test Performed/ Reagents & Result \\
\hline \multirow{2}{*}{ Alkaloids } & Bouchardat & + \\
& Dragendorff & + \\
Flavonoids & Mayer & + \\
& Shinoda & + \\
Tannins & Ammonia & + \\
& Gelatin & + \\
Saponins & Lead acetate & + \\
Steroids and terpenoids & Foam & + \\
\hline
\end{tabular}

Table 2: Physicochemical parameter of powder of Tithonia diversifolia.

\begin{tabular}{clc}
\hline No & Parameter & Result \\
\hline 1 & Moisture content loss on drying & $11.27 \%$ \\
& Ash Value & \\
2 & - Total Ash & $10.29 \%$ \\
& - Acid insoluble ash & $0.72 \%$ \\
& Extractive values & \\
3 & - Ethanol soluble extractive & $4.73 \%$ \\
& - Water soluble extractive & $18.01 \%$ \\
\hline
\end{tabular}

spots and the most dominant spot had a Rf value of 0.675 . On the other hand, the dichloromethane extract obtained 7 spots and the most dominant spot had Rf value of 0.8625 . Whereas, ethanol extract $70 \%$ got 3 spots and the most dominant Rf value of 0.625 .

Flourescence character of powder and ethanol extract $70 \%$ used reagent $\mathrm{NaOH} 5 \%, \mathrm{H}_{2} \mathrm{SO}_{4} 50 \%, \mathrm{HCl} 2 \mathrm{~N}$ and $\mathrm{HNO}_{3} 50 \%$. The results observation of powder visually with green color and ethanol extract $70 \%$ with brown color. Fluorescence provided by a drug is one of the several methods used for analyzing crude drugs. The different compounds produce specific fluorescence characteristics which are help full for preliminary chemical study as well as for standardization of specific plant materials. The colour was seen at day light and ultraviolet rays at $254 \mathrm{~nm}$ and $366 \mathrm{~nm}$ for observing any specific fluorescence. The results of the fluorescence of the powder and extract of Tithonia diversifolia are summarized in Tables 3 and 4.

Flavonoid determination of ethanol extract $70 \%$ leaf paitan done qualitatively and quantitatively. From qualitative results, quercetin compounds have a value of $\mathrm{Rf}=0.9$ equivalent to flavonoid compounds from paitan leaf ethanol extract. In the quantitative analysis, the determination of total flavonoid levels uses UV-VIS Spectrophotometry. The result also obtained the spesific maximum wavelength of quercetin compound which is $440 \mathrm{~nm}$ wavelength. The data analysis show the total flavonoid content that were contained in paitan leaf ethanol extract (Tithonia diversifolia (Hemsl.) Gray) was $69.1653 \mathrm{mg}$ calculated as quercetin / g extract. 
Table 3: Chromatographic evaluation of different extract Tithonia diversifolia.

\begin{tabular}{|c|c|c|c|c|c|}
\hline Extract & Solvent system (Ratio) & No.of spots & Visual & $\begin{array}{l}\text { Spraying reagent (10\% } \\
\text { H2SO4) }\end{array}$ & $\begin{array}{c}\text { Rf } \\
\text { (UV } 366 \mathrm{~nm})\end{array}$ \\
\hline Hexane & Hexane-DCM (4:6) & 6 & $\begin{array}{l}\text { 1.Green } \\
\text { 2.Yellow } \\
\text { 3.Yellow } \\
\text { 4.Green } \\
\text { 5.Green } \\
\text { 6.Yellow }\end{array}$ & $\begin{array}{c}\text { Brown } \\
\text { Yellowish } \\
\text { Pink } \\
\text { Yellowish } \\
\text { Light brown } \\
\text { Pink }\end{array}$ & $\begin{array}{l}0.05 \\
0.25 \\
0.40 \\
0.45 \\
0.68 \\
0.95\end{array}$ \\
\hline DCM & Chloroform-Methanol (9:1) & 7 & $\begin{array}{c}\text { 1.Green } \\
\text { 2.Green } \\
\text { 3.Yellow } \\
\text { 4.Yellow } \\
\text { 5.Green } \\
\text { 6.Green } \\
\text { 7.Blue }\end{array}$ & $\begin{array}{l}\text { Light blue } \\
\text { Light blue } \\
\text { Yellowish } \\
\text { Yellowish } \\
\text { Yellowish } \\
\text { Pink } \\
\text { Light blue }\end{array}$ & $\begin{array}{l}0.06 \\
0.23 \\
0.26 \\
0.35 \\
0.38 \\
0.55 \\
0.86\end{array}$ \\
\hline Etanol & Etil asetat-Etanol 96\% (5:5) & 3 & $\begin{array}{l}\text { 1.Green } \\
\text { 2.Green } \\
\text { 3.Green }\end{array}$ & $\begin{array}{l}\text { Light blue } \\
\text { Light blue } \\
\text { Light blue }\end{array}$ & $\begin{array}{l}0.63 \\
0.78 \\
0.93\end{array}$ \\
\hline
\end{tabular}

Table 4: Fluorescent analysis of various powder and extract Tithonia diversifolia.

\begin{tabular}{cccc}
\hline Material Powder & Day Light & Short UV (254 $\mathrm{nm})$ & Long UV $(366 \mathrm{~nm})$ \\
\hline+ Aquadest & Dark green & Green & - \\
$+2 \mathrm{~N} \mathrm{HCL}$ & Dark brown & Light green & Green \\
$+50 \% \mathrm{H} 2 \mathrm{SO} 4$ & Brown & Green & Brown \\
$+50 \% \mathrm{HNO} 3$ & Yellowish brawn & Yellowish green & Brown \\
$+5 \% \mathrm{NaOH}$ & Greenish brawn & Greenish brawn & Brown \\
Ethanol Extract & & & Light yellow \\
+ Aquadest & Brown & Yellow & Yellow \\
$+2 \mathrm{~N} \mathrm{HCl}$ & Brown & Yellow & Yellow \\
$+50 \% \mathrm{H} 2 \mathrm{SO} 4$ & Brown & Yellowish brown & Yellowish brown \\
$+50 \% \mathrm{HNO} 3$ & Yellowish brown & Yellowish brown & Yellowish brown \\
$+5 \% \mathrm{NaOH}$ & Yellowish brown & &
\end{tabular}

\section{CONCLUSION}

Pharmacognosy study is an important starting point for the standardization of traditional medicines because only good quality of simplicia produces a good quality of traditional medicines. Authenticity is a general introduction of simplicia which are sensoric characteristics, macroscopic and microscopic evaluation. The result of physicochemical parameter test showed that the total was $10.29 \%$ ash value, $0.72 \%$ acid insoluble ash value, $4.73 \%$ ethanol soluble extract value, $18.01 \%$ water soluble extract value and $11.27 \%$ moisture content. Phytochemical screening tests found alkaloid, flavonoids, tannins, saponins and terpenoids. The chromatography profile of $n$-hexane extract was obtained 6 spots, dichloromethane extract obtained 7 spots and ethanol extract $70 \%$ got 3 spots. Levels of flavonoids contained in paitan leaf ethanol extract was $69.1653 \mathrm{mg}$ calculated as quercetin / g extract.

\section{REFERENCES}

1. Hanifa RA, LukmayaniY. Antioxidant activity and determination of total flavonoid of paitan (Tithonia diversifolia (Hemsley) A. Gray). UNISBA Journals, Bandung. $2015 ; 164$.

2. Zirconia A. Identification of flavonoid compounds from Paitan ((Tithonia diversifolia (Hemsley) A. Gray) Leaves, Sains and Tecnology University, UIN Bandung. 2015;17.

3. Ezeonwumelu JOC, Omolo. Studies of phytochemical screening, acute toxicity and anti-diarrhoeal effect of aqueous extract of kenyan Tithonia diversifolia Leaves in Rats. Dalam: British Journal of Pharmacology and Toxicology. Department of pharmacology and toxicology. Nigeria. 2012;128.

4. Mardihusodo HR, Wahyuningsih MSH. Cytotoxicity of ethanol extract of kembang bulan (Tithonia diversifolia (Hemsley) A. Gray) dan rimpang kencur (Kaempferia galanga L.) on widr cells: Faculty of Medicine Journals. University of Gajah Mada. Yogyakarta. 2011;175.
5. Darmawi AR, Saleh C, Kartika R. Antihiperglicemic activity of hexane (Tithonia diversifolia A. Gray) on male white rats: Chemistry Journal Mulawarman University Mulawarman. Samarinda. 2015;59.

6. Redha A. Flavonoid: Structure, antioxidant and the role in biological systems: agricultural technology journals. Politeknik Negeri Pontianak. Pontianak. 2010;197.

7. Rais IR. Isolation and determination of flavonoid of sambiloto herbs (Androgaphis paniculata (Burm.F) Ness). Faculty of Pharmacy Journals. University of Ahmad Dahlan. Yogyakarta. 2015;101.

8. Wallis TE. Practical pharmacognosy, 5 th Ed.J \& A Churchill Ltd, London, 1984;111-7.

9. Departemen Kesehatan Republik Indonesia. Farmakope herbal .Edisi I. Jakarta: Directorat General of Drug and Food Control .Jakarta. 2008;169-71.

10. Kokashi CJ, Kokashi RJ, Sharma M. Fluorescence of powdered vegetable drugs in ultra-violet radiation. Journal American Pharm Assoc.1958;47:715-7.

11. Wagner H, Bladt S, Zgainski EM. Plant drug analysis, a thin layer chromatography atlas, Springer-Verlag, Berlin, Germany, 1984;1-17.

12. Chang CC, Yang MH, Wen HM, Chern JC. Estimation of total flavonoid content in propolis by two complementary colorimetric methods. Journal of Food and Drug Analysis. 2002;10(3):178-82.

13. Departemen Kesehatan Republik Indonesia (Health Department of Republic Indonesia) Materia Medika Indonesia Edisi V. : Directorat General of Drug and Food Control .Jakarta.1989, xvii.

14. Departemen Kesehatan Republik Indonesia. Parameter standar umum ekstrak tumbuhan obat. Diretorat general of drug and food control . Jakarta. 2000;1-18.

15. Harborne J.B. Methods phytochemical : A guide to modern techniques of plant analysis. Editors: Kosasih padmawinata dan iwang soediro.bandung institute of technology. Bandung. 1987;102:238-9.

16. Hayati Elok, Nur Halimah. Phytochemical test and brine shrimp lethality test against Artemia salina leach of anting - anting (Acalypha Indica Linn.) plant extract. Journal Universitas Islam Maulana Malik Ibrahim. Malang. 2010;53-103.

17. Marliana E. Antioxidants activity and analysis of secondary metabolite from stem Spatholobus ferrugineus (Zoll \& Moritzi) benth. Research of Journals MIPA. University of Mulawarman. Kalimantan. 2007;23-9. 
18. Sulistyani N, Marliana E. Antifungal activity of ethanol extract of stembark binahong (Anredera cardifolia (tenoe) Steen.) on Candida albicans; Pharmaceutical Scientific Journals.University of Ahmad Dahlan. Yogyakarta. $2011 ; 51-62$.
19. Sutrisnayanti LN. Isolation dan identification terpenoid as antibacterial on meniran herb (Phyllanthus niruri Linn). Chemistry Journals. University of Udayana. 2008:31-9.

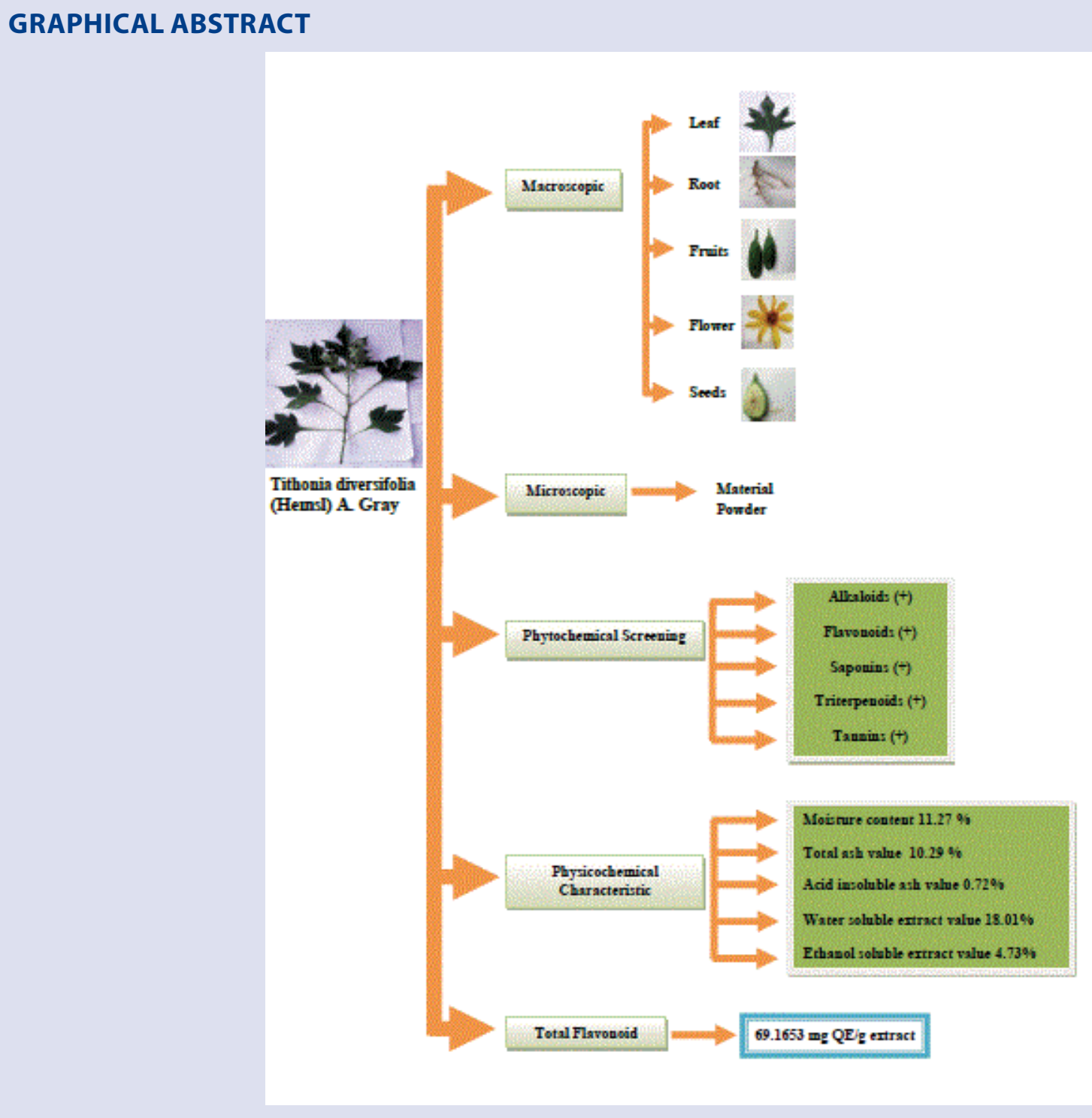

\section{ABOUT AUTHOR}

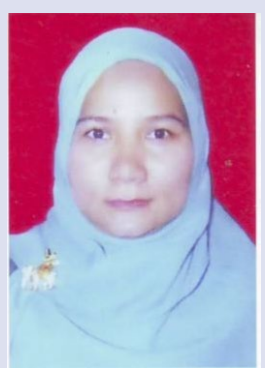

Vera Ladeska was born in Padang, West Sumatra, December 13, 1973. Graduated with a Bachelor of Pharmacy (S1) from Andalas University in Padang 1997, a Pharmacist Professional Program at Andalas University in Padang (1998), and completed a Masters Program in natural product at Andalas University (2005). Since 2000 he has been teaching staff at the Indonesian College of Pharmacy (STIFI) Padang. At STIFI he taught Pharmacognosy and Phytochemistry courses. In 2007 he moved to Jakarta and worked at the Muhammadiyah University Prof.DR.HAMKA (UHAMKA) Jakarta until now. At UHAMKA he teaches courses on traditional medicine and phytopharmaca, pharmacognosy, phytochemistry, safety and efficacy of natural medicine. At present he is in charge of UHAMKA's phytochemical laboratory.

Cite this article: Ladeska V, Dewanti E, Sari DI. Pharmacognostical Studies and Determination of Total Flavonoids of Paitan (Tithonia diversifolia (Hemsl.) A. Gray. Pharmacog J. 2019;11(6):1256-61. 